ICH 2019

International Conference on Humanities

\title{
STAKEHOLDERS' MAPPING BASED ON CULTURES IN COASTAL AREA OF SURABAYA
}

\author{
Mas Roro Lilik Ekowanti, MS (a)*, Wildan Taufik Raharja, S.IAN., M.PSDM (b) \\ *Corresponding author
}

(a) Public Administration, Hang Tuah University, Surabaya, Indonesia, lilik.ekowanti@hangtuah.ac.id

(b) Public Administration, Hang Tuah University, Surabaya, Indonesia, raharja.wildan@hangtuah.ac.id

\begin{abstract}
Surabaya City is the biggest city in the province of East Java. Not only physical development, but social, economic and human resource sector are also developed. There are disparity in development in the SurabayaCity, especially in north coastal area of Surabaya in which the majority of people have low income. The problem is that many people refused to follow the programs. The Government of Surabaya must find a new approach to intervene the implementation of development programs. This research aims to map stakeholders based on cultures that have a significant influence on development and identify relevant stakeholders who have roles in the development. The research method used a qualitative approach with case studies in which researchers investigate carefully, event, program, process activity, or group of individuals. Techniques to determine informants used purposive and snowball techniques. The study used triangulation method for checking the validity of data and used 6 stages of qualitative research data analysis approaches. The result of the study shows that religious stakeholders are the dominant factor for intervening the government program implementation. The future research shall discuss about how to intervene a policy with cultural stakeholders mapping approach in improving the program of development and community welfare in the Surabaya City.
\end{abstract}

2357-1330 C 2020 Published by European Publisher.

Keywords: Stakeholder, cultural, local government, development, Surabaya. 


\section{Introduction}

Every stakeholders may influence a particular project or program either positively or in a negative way. The concept of interest, participation, social continuity and continual development are related to one another and collectively able to contribute to social changes (Martinez \& Olander, 2015). Gyan and Ampomah (2016) suggested project managers to pay attention to the relationship of stakeholders in the initiation, design and implementation of project to avoid negative impacts of stakeholders in development. A tight relationship between primary stakeholder and secondary formed could ensure the service of poverty alleviation program to be well achieved in the community (Usadolo \& Caldwel, 2016). Conflict precaution and management programs must be structured in a process of community development to contribute minimize potential conflicts and stakeholder disputes.

Stakeholder are very important in order to decide on what must be done with information, because a type of similar information could assist stakeholders to overcome different responsibilities in various methods (Granström, 2008). Stakeholders are able to generate more stable decision which integrates longterm and short-term strategy perspectives (Bottenberg et al., 2016). In several cases, higher government intervention is very important to give important meaning to executive institutions and avoid other dominant stakeholders with potential to slow down a project (Pandey \& Gupta, 2016). Every process of stakeholder involvement must be evaluated through simple assessment methodology and in a wider context stakeholders' involvement activities must be assessed (Tomkiv et al., 2017).

Surabaya City as a big city and an economic center in East Java shows a fairly rapid development. The success of the development is inseparable from the role of all participating stakeholders ranging from planning to evaluation of development programs. The success of the development of Surabaya City can be seen from the human development index (HDI) which tends to rise. The City's Human Development Index (HDI) in the last 4 years tends to rise. In 2010 IPM of Surabaya City was 65.36 and rose to 66.06 in 2011, then in 2012 it rose to the level of 66.74. The increase in the IPM of Surabaya City continued in the following years, namely in 2013 to 67.55 and in 2014 it rose to 68.14. Then in the 2012 Human Development Index of Bulak Subdistrict was 22nd better than Kenjeran Subdistrict which was in position 25 out of 31 sub-districts in Surabaya City.

The region of Bulak and Kenjeran and their surrounding areas are the regions in Surabaya that are relatively behind the growth rate compared to other regions. However, this region has the prospect of developing especially the tourism sector along with the operation of Suramadu Bridge and Surabaya Bridge. The problem faced is the dependence of income from fishing with results that are not sufficient to meet daily needs. To develop the economy of coastal communities, Surabaya City Government has carried out both physical and non-physical developments such as Bulak Fish Center (Sentra Ikan Bulak-SIB) and others. Several program innovations have been carried out by Surabaya City Government to stimulate developments. However, this still cannot trigger the development of SIB. The root of the problem that can be identified is that there are still some stakeholders who have not supported SIB and tend to reject government programs. Therefore, this research wants to identify stakeholders who have a very strong influence on the implementation of development programs in the coastal areas of Surbaya City. 


\section{Problem Statement}

Some approaches such as top-down and bottom-up in the coastal development of the city of Surabaya are considered to be not optimal, therefore it is necessary to use other approaches such as the cultural approach. This cultural approach will map stakeholders who are considered to have large influences on their environment. These stakeholders will later become agents of change and give influence to their environment to improve community participation in empowerment programs facilitated by the government.

The focus of this research is on stakeholder mapping based on elements of universal culture. Stakeholder mapping links policy objectives and group of stakeholders through action plans, and focuses on internal consistency between policy objectives, action plans and institutions (Mehrizi et al., 2009). Stakeholder mapping is made to appraises the constituent environment based on the level at which stakeholders have the attributes of power, urgency and legitimacy (Friedman \& Mason, 2004)). With this mapping, several situational factors can be assessed by demonstrating the usefulness of stakeholder analysis for policy makers to strategically organize the constituent groups and explain how problems can be resolved. Identifying and determining stakeholder priorities (as an important part of stakeholder analysis) is considered an important element (Slabá, 2016).

The most commonly used technique for stakeholder analysis or mapping places stakeholders on a matrix that has two main attributes of stakeholders as analysis blades. (Mathur et al., 2007). Matrix is used to stakeholders plotting based on their fields (horizontal axis) and (vertical axis) relative to change initiatives (Shirey, 2012). According to Dean (2001), stakeholders can be divided into two types, namely primary stakeholders and secondary stakeholders. Then De Lopez (as cited in Reed et al., 2009) maps stakeholders based on the level of influence (power) and interest which are categorized as follows: (1) Stakeholders with a high level of interest but have low power are classified as Subjects. (2) Stakeholders with high levels of interest and power are classified as Key Players. (3) Stakeholders with a low level of interest and power are classified as other followers (Crowd). (4) Stakeholders with a low level of interest but have high power are classified as supporters (Contest setters). While Koentjaraningrat (2004) described seven elements of universal culture that can certainly be found throughout the world, namely: religious systems and religious ceremonies, social systems and organizations, knowledge systems, languages, arts, living livelihood systems, and systems of technology and equipment.

\section{Research Questions}

The research question for this study is, how is the stakeholders' mapping based on culture in the coastal area of Surabaya City?

\section{Purpose of the Study}

The purpose of stakeholder mapping based on culture as policy intervention in improving the synergy of the development program and the welfare of the people in the coastal area of Surabaya City is based on the following description:

1. Mapping the cultures that have a significant influence on development in the coastal area of Surabaya City 
2. Identifying relevant stakeholders who have roles in development in the coastal area of Surabaya City.

\section{Research Methods}

\subsection{Research approach}

According to Creswell (2013), in determining the approach, a research must clarify philosophical ideas that will be exposed. This explanation will determine which approach will be used in the study. This study uses a philosophical advocacy and participatory paradigm or assumptions. Because basically the results of this study will direct the agenda of changing a policy considered not to represent the desires of various groups. This study uses a case study research strategy which researchers inspect carefully a process, program, activity, event, or group of individuals. The idea behind qualitative research is to deliberately choose the informants or participants and the location of research that can help researchers to understand the problem under study.

\subsection{Data collection technique}

In this study, the researcher chose purposive and snowball techniques. The selected informants were those who were considered the most knowledgeable in understanding the problems in this study. Data consisted from primary data and secondary data. The Primary data was taken from deep interviews. All interview guide were read by the interviewers in order to make good interpretative and same perception (Neergaard \& Ulhøi, 2007). Research starts with a question of research and collects primary data from focus group to answer this research question (Lune \& Berg, 2017). The number of informants in this study was 14 people. The informants were chosen because they have influence in formulating policies, such as religious leaders, and leaders of community groups (formal and informal), and the community. Then, The secondary data is data obtained by researchers from existing sources or reused for another question of research (Hox \& Boeije, 2005). Secondary data in this study were government documents, journals, and literature reviews. The location of the research was in the Coastal Area of Surabaya including Kenjeran Subdistrict and Bulak Subdistrict which consisted of 4 villages, namely Sukolilo Baru, Village Kenjeran Village, Kedung Cuwek Village and Tambak Wedi Village.

\subsection{Technique of data analysis}

Data analysis techniques adopted in this study is described as follows. There were 6 stages of qualitative research data analysis. Managing and preparing data, reading all data, analyzing more details by coding data, implementing the coding process, showing how the descriptions and themes will be restated in qualitative narratives or reports, and interpreting data (Creswell, 2013). The technique of checking the validity of the data used triangulation. There were 4 kinds of triangulation as a technique for checking the validity of data, namely triangulation of sources, triangulation with methods, triangulation of honesty of researchers, triangulation with theories (Moleong, 2002) 


\section{Findings}

\subsection{Cultural Element}

People who live in coastal areas have different cultural forms than people who live in the centre of the city. Geographical location determines the pattern of life in certain communities. Thus, the pattern or way of life of the community can form certain characteristics that are manifested in culture and its elements. Besides having its own form, culture also has elements. This was stated by Koentjaraningrat (2004) which divides cultural elements into 7 elements (Table 01 ):

Table 01. Description of Cultural Classification

\begin{tabular}{|c|c|c|c|c|}
\hline $\begin{array}{l}\text { Cultural } \\
\text { Dimension }\end{array}$ & SukoliloBaru & KedungCowek & Kenjeran & TambakWedi \\
\hline Religion & $\begin{array}{l}\text { - The majority are } \\
\text { Muslim. } \\
\text { - Muhammadiyah and } \\
\text { Nahdatul Ulama groups } \\
\text { are equally strong } \\
\text { - Religious events, such as } \\
\text { yasinan or tahlil } \\
\text { (Nahdatul Ulama) } \\
\text { recitation of aisyi'ah } \\
\text { (Muhammadiyah) }\end{array}$ & $\begin{array}{l}\text { - The majority are } \\
\text { Muslim } \\
\text { - More inclined towards } \\
\text { the Nahdatul Ulama } \\
\text { group } \\
\text { - Religious events, such } \\
\text { as yasinan or tahlil } \\
\text { (Nahdatul Ulama) }\end{array}$ & $\begin{array}{l}\text { - The majority are } \\
\text { Muslim } \\
\text { - More inclined } \\
\text { towards the Nahdatul } \\
\text { Ulama group } \\
\text { - Religious events, } \\
\text { such as yasinan or } \\
\text { tahlil (Nahdatul } \\
\text { Ulama) }\end{array}$ & $\begin{array}{l}\text { - The majority are } \\
\text { Muslim } \\
\text { - More inclined } \\
\text { towards the } \\
\text { Nahdatul Ulama } \\
\text { group } \\
\text { - Religious events, } \\
\text { such as yasinan } \\
\text { or tahlil } \\
\text { (Nahdatul } \\
\text { Ulama) }\end{array}$ \\
\hline Organization & $\begin{array}{l}\text { Structured, strong } \\
\text { religious organization }\end{array}$ & $\begin{array}{l}\text { Structured, weak } \\
\text { religious organization }\end{array}$ & $\begin{array}{l}\text { Structured, strong } \\
\text { religious organization }\end{array}$ & $\begin{array}{l}\text { Structured, strong } \\
\text { religious } \\
\text { organization }\end{array}$ \\
\hline Knowledge & $\begin{array}{l}\text { - For the young group, the } \\
\text { majority of them take } \\
\text { high school education } \\
\text { - For the older group, the } \\
\text { majority are elementary } \\
\text { and junior high school } \\
\text { graduates }\end{array}$ & $\begin{array}{l}\text { For the young group, } \\
\text { the majority of them } \\
\text { take high school } \\
\text { education } \\
\text { For the older group, the } \\
\text { majority are elementary } \\
\text { and junior high school } \\
\text { graduates }\end{array}$ & $\begin{array}{l}\text { For the young group, } \\
\text { the majority of them } \\
\text { take high school } \\
\text { education } \\
\text { For the older group, } \\
\text { the majority are } \\
\text { elementary and junior } \\
\text { high school graduates }\end{array}$ & $\begin{array}{l}\text { - For the young } \\
\text { group, the } \\
\text { majority of them } \\
\text { take high school } \\
\text { education } \\
\text { - For the older } \\
\text { group, the } \\
\text { majority are } \\
\text { elementary and } \\
\text { junior high } \\
\text { school graduates }\end{array}$ \\
\hline Language & Javanese (Surabaya) & Javanese (Surabaya) & Javanese (Surabaya) & $\begin{array}{l}\text { Javanese } \\
\text { (Surabaya) }\end{array}$ \\
\hline Art & $\begin{array}{l}\text { Drum bands are more } \\
\text { religious. }\end{array}$ & $\begin{array}{l}\text { Banjari, Hadroh, Pencak } \\
\text { Silat }\end{array}$ & Hadrah, banjari & Hadrah, banjari \\
\hline Livelihood & $\begin{array}{l}\text { Fishermen and sea food } \\
\text { entrepreneurs }\end{array}$ & Fisherman & $\begin{array}{l}\text { Fishermen and sea food } \\
\text { entrepreneurs }\end{array}$ & entrepreneur \\
\hline Technology & $\begin{array}{l}\text { Engine boats, still } \\
\text { traditional fishing } \\
\text { equipment and still } \\
\text { traditional seafood } \\
\text { processing equipment }\end{array}$ & $\begin{array}{l}\text { Engine boats, still } \\
\text { traditional fishing } \\
\text { equipment and still } \\
\text { traditional seafood } \\
\text { processing equipment }\end{array}$ & $\begin{array}{l}\text { Engine boats, still } \\
\text { traditional fishing } \\
\text { equipment and still } \\
\text { traditional seafood } \\
\text { processing equipment }\end{array}$ & $\begin{array}{l}\text { Engine boats, still } \\
\text { traditional fishing } \\
\text { equipment and still } \\
\text { traditional seafood } \\
\text { processing } \\
\text { equipment }\end{array}$ \\
\hline
\end{tabular}

Source: Processed by the researcher

\section{Religious system and religious ceremonies}

Islamic style is easily found in Kenjeran coastal communities and its surroundings. Apart from that, there are 2 large Islamic organizations namely Nahdhatul Ulama (NU) and Muhammadiyah. Most of the 
followers of Islam follow or are members of the NU. The teachings of Islam and the activities of NU has become a major theme of the Kenjeran coastal community. This is reflected in the number of religious activities such as yasinan, tahlil, sholawatan, and others. For NU followers, the teachings of senior preachers have become part of the way of life of coastal residents. This can be seen from the role of Islamic boarding schools in the region. This is in line with the religious system theory revealed by Koentjoroningrat that religious systems are integrated systems between religious beliefs and practices. Religious systems include belief systems, values systems and life views, religious communication, and religious ceremonies.

\section{Community systems and organizations}

In coastal communities, religious elements are determinants in the order of social organizations. This can be known from the number of people who are members of religious organizations, namely NU. This is in line with what was stated by Koentjaraningrat (2004), who said that each community group had a life governed by customs and policy which is created by their groups. In the life of coastal communities it is greatly affected by the religious system in the NU organization.

\section{Knowledge System}

The livelihoods of the most people in the coastal areas of Kenjeran and its surroundings are fishermen and entrepreneurs who produce marine products. Therefore, the level of formal education enjoyed in the region is mostly elementary, middle and high school graduates. They feel that there is no need to get an education that is too high because basically they only rely on knowledge of seasons, weather, wind, and natural conditions that affect the amount of catch or production of processed seafood, which is derived from their experience as fishermen or inherited knowledge from generation to generation. This is in line with the theory put forward by Koentjaraningrat (2004) that knowledge systems are related to systems of living equipment and technology where knowledge systems include human knowledge of the several elements used in their lives.

\section{Language}

In the coastal communities of Kenjeran and its surroundings, the language used daily has its own characteristics. Indeed, in everyday life the majority uses Javanese, but with a dialect similar to Madurese. The use of Javanese is also used at certain age groups, namely in the age group of 25 and under. Whereas people who understand the Madura language range in age of 30 to above. However, most of them use Javanese for their daily use with distinctive dialect characteristics from Javanese in Surabaya. This is like what Koentjaraningrat (2004) said that language is a form of symbolizing human beings both verbally and in writing to communicate.

\section{Arts}

Art outlines are mapped into 3 forms, namely art, sound art, and dance. In the Kenjeran and surrounding coastal communities, artistic activities that appear are influenced by the religious elements adopted by citizens. Most of the population in the region are Muslim and are members of NU or Muhammadiyah organizations. Therefore, the emerging art activities are dominated by Islamic art such as hadrah, nasyid, banjari and so on.

\section{Livelihood System}

Livelihood is the most important thing of all community activities in order to maintain their lives. In the results of interviews from the 4 coastal villages, it can be seen that most of the livelihoods of people 
living in coastal or coastal areas are fishermen. Indeed, in the last period the number of fishermen has declined but not significantly. Coastal communities are still traditional communities seen from the system of equipment and technology they use. Because coastal communities are still traditional people, their livelihoods cannot be separated from their geographical conditions, namely fishermen. The livelihood is included in 5 economic systems in traditional communities, namely: Hunting and gathering, raising livestock, farming in the fields, fishing, and planting crops with irrigation systems

7. Systems of technology and equipment

Humans in their lives always try to fulfil their needs so that they can survive and develop. Equipment for life is a sign that human civilization has been formed. In coastal communities, the geographical conditions require them to be able to survive with marine products. As with the explanation of the third form of culture, which is a form of physical culture, coastal communities have a lot of equipment that supports their activities as fishermen. Nets, boats, marine products are an example of a system of equipment used by coastal communities. Because the majority of the population are fishermen, their equipment system is not far from the function of fishing and processing fish.

\subsection{Stakeholder analysis}

Based on the results of interviews and observations in the field, mapping of stakeholders based on the level of influence (power) and interest, there are 3 groups that become stakeholders in the development process (Table 02 and Figure 01).

Table 02. Description of Stakeholder Classifications

\begin{tabular}{|c|c|c|c|c|}
\hline $\begin{array}{l}\text { Stakeholder } \\
\text { Dimension }\end{array}$ & SukoliloBaru & KedungCowek & Kenjeran & TambakWedi \\
\hline Subject & $\begin{array}{l}\text { Coastal } \\
\text { Community }\end{array}$ & $\begin{array}{l}\text { Coastal } \\
\text { Community }\end{array}$ & Coastal Community & Coastal Community \\
\hline Key Player & $\begin{array}{l}\text { Bappeko of } \\
\text { Surabaya city, } \\
\text { Bulak sub- } \\
\text { district, } \\
\text { SukoliloBaru } \\
\text { village, coastal } \\
\text { community, } \\
\text { fishermen group }\end{array}$ & $\begin{array}{l}\text { Bappeko of } \\
\text { Surabaya city, } \\
\text { Bulaksub-district, } \\
\text { KedungCowek } \\
\text { Village, coastal } \\
\text { community, } \\
\text { fishermen group }\end{array}$ & $\begin{array}{l}\text { Bappeko of } \\
\text { Surabaya city, } \\
\text { Bulak sub- } \\
\text { district,Kenjeran } \\
\text { Village, coastal } \\
\text { community, } \\
\text { fishermen group }\end{array}$ & $\begin{array}{l}\text { Bappeko of Surabaya } \\
\text { city,Kenjeran sub- } \\
\text { district,TambakWedi } \\
\text { Village, coastal } \\
\text { community, } \\
\text { fishermen group }\end{array}$ \\
\hline Crowd & $\begin{array}{l}\text { NGOs and } \\
\text { Private Parties }\end{array}$ & $\begin{array}{l}\text { NGOs and Private } \\
\text { Parties }\end{array}$ & $\begin{array}{l}\text { NGOs and Private } \\
\text { Parties }\end{array}$ & $\begin{array}{l}\text { NGOs and Private } \\
\text { Parties }\end{array}$ \\
\hline Contest Setter & Kiai or ustadz & Kiai or ustadz & Kiai or ustadz & Kiai or ustadz \\
\hline
\end{tabular}

Source: Processed by the researcher

1. Stakeholders with high levels of interest and power are classified as Key Players. These stakeholders include Surabaya City Bappeko, Kenjeran Subdistrict, Tambak Wedi Village, coastal communities, and fishermen groups. Surabaya City Development Planning Agency (Bappeko) which has the task of carrying out the formulation and implementation of Regional policies in the field of development planning has a great importance and influence for development in coastal areas. Bappeko has the function of formulating technical policies for development planning, coordinating the preparation of development 
plans, as well as guiding and implementing tasks in the field of development planning. Then Bulak Subdistrict, which is the level of coordination of development programs from the city government to the village, has a very vital role in translating and coordinating development. Whereas Tambak Wedi Village which is the government level closest to the community is a government institution that can succeed in development. Then the community in the development process must be involved starting from the process of planning, implementing, and evaluating development. One community group that must fully participate in the development process in the coastal area of Tambak Wedi Village is the fisherman group. However, the data obtained for the Tambak Wedi village that needs to be considered is the fishermen, but other sectors such as the plan to develop religious tourism areas also need to be considered properly by the government. The condition of the community underwent changes, not all of them are now fishermen seen from the data above.

2. Stakeholders with a low level of interest but have high power are classified as supporters (Contest setters). Included in this category are various non-formal organizations that grow in the community, such as religious organizations which includes Nahdatul Ulama and Muhammadiyah, kyai or ustadz (preachers) who are role models for the surrounding community. Since kyai or ustadz in areas that have a significant religious system have many interactions with the community, they have important influence in the development process.

3. Stakeholders with a low level of interest and power are classified as Other Followers (Crowd). This group is a local and private NGO. From the results of interviews with various sources, there were no NGOs active in the development process in Tambak Wedi Village area. Then the private sector in this case are private companies that can become government partners in the development process.

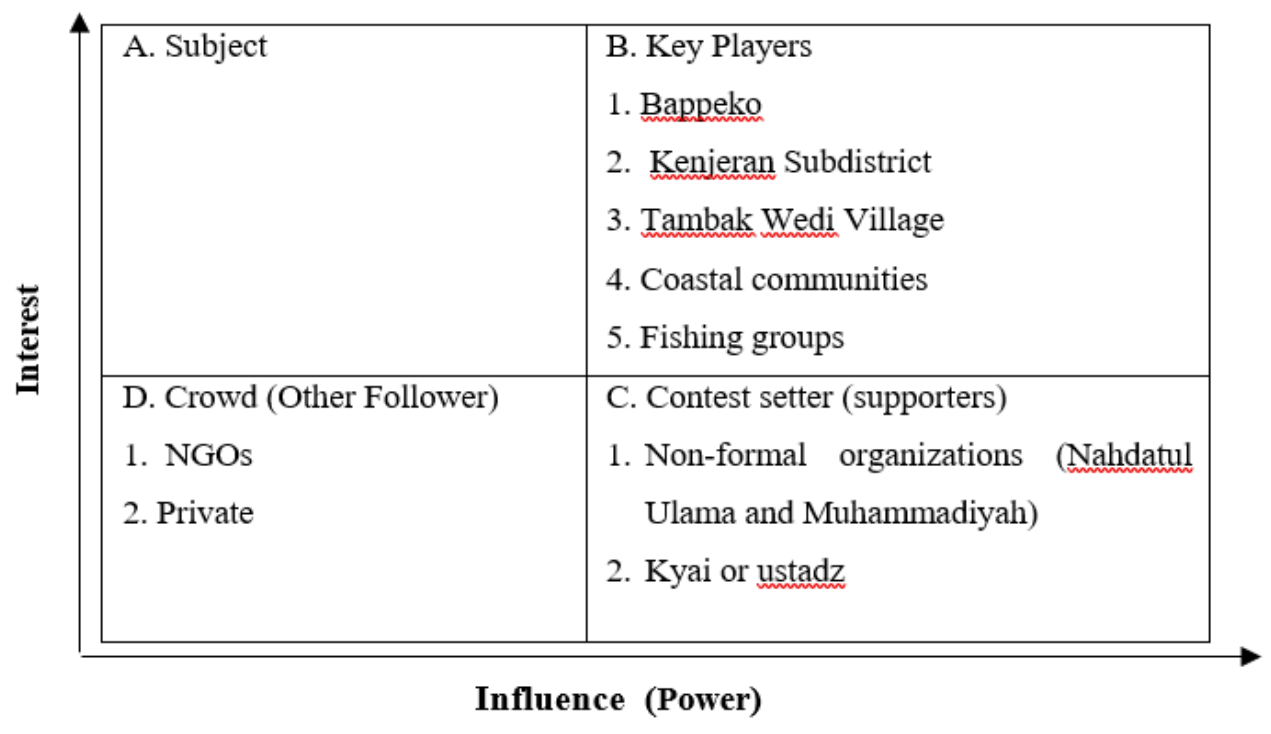

Figure 01. Description of Stakeholder Classification (Source: Processed by the researcher)

\section{Conclusion}

The best cultural elements that have potential to be intervened in policies to improve the synergy of the development program and the welfare of the people in coastal area of Surabaya is through the community's religious system. The religious system besides being the basis of people's lives is also a 
means to communicate or socialize between communities. The religious systems in the area are homogeneous with the majority of the population being Muslim. We would like to offer the strategies in intervening policies by using a religious element approach in the development process. We hope that every development can be supported by all stakeholders. The limitations of this research are that this research used a case study approach that only focused on the northern coastal area of the city of Surabaya while other regions have different life cultural structures. The results of this study cannot be used directly as a reference in formulating policies in other regions. The future research of this study shall make strategies in public policy on how to intervene a policy through stakeholders who have been mapped in this study.

\section{Acknowledgments}

The research was supported by City Development Planning Board of Surabaya (BAPPEKO). We thank our colleagues from Hang Tuah University who provided expertise that have greatly assisted the research and the informants for sharing their insights and knowledges. We would also like to show our gratitude to committees of International Conference on Humanities 2019 who have given us the oppurtunity to publish our research.

\section{References}

Bottenberg, K., Tuschke, A., \& Flickinger, M. (2016). Corporate Governance Between Shareholder and Stakeholder Orientation. Journal of Management Inquiry, 26(2), 165-180. https://doi.org/10.1177/105649261 6672942

Creswell, J. W. (2013). Research design. Pustaka Pelajar.

Dean, J. (2001). Directing Public Companies: Comapny Law \& Stakeholder Society. Cavendish Publishing Limited.

Friedman, M. T., \& Mason, D. S. (2004). A Stakeholder approach to Understanding Economic Development Decision Making: Public Subsidies for Professional Sport Facilities. Economic Development Quarterly, 18(3), 236-254. https://doi.org/10.1177/0891242404265795

Gyan, C., \& Ampomah, A. O. (2016). Effects of Stakeholder Conflicts on Community Development Projects in Kenyase. SAGE Open, 1-8. https://doi.org/10.1177/2158244016635254

Granström, R. (2008). A system and stakeholder approach for the identification of condition information: A case study for the Swedish railway. Proceedings of the Institution of Mechanical Engineers, Part F: Journal of Rail and Rapid Transit, 222(4), 399-412. https://doi.org/10.1243/09544097jrrt183

Hox, J. J., \& Boeije, H. R. (2005). Data Collection, Primary vs. Secondary. Encyclopedia of Social Measurement, 1, 593-599 . https://dspace.library.uu.nl/handle/1874/23634

Koentjaraningrat. (2004). Kebudayaan, Mentalitas dan Pembangunan [Culture, Mentality and Development]. PT Gramedia Pustaka Utama

Lune, H., \& Berg, B. L. (2017). Qualitative Research Methods for the Social Sciences (9th edition). Pearson Education Limited.

Slabá, M. (2016). Stakeholder profile and stakeholder mapping of SMEs. Littera Scripta, 9(1), 124-139. http://journals.vstecb.cz/wp-content/uploads/2016/06/Slab\%C3\%A1.pdf

Martinez, C., \& Olander, S. (2015). Stakeholder participation for sustainable property development. 8th Nordic Conference on Construction Economics and Organization, Procedia Economics and Finance, 21, 57-63. https://doi.org/10.1016/S2212-5671(15)00150-1

Mathur, V. N., Price, A. D. F., Austin, S., \& Moobela, C. (2007). Defining, identifying and mapping stakeholders in the assessment of urban sustainability. M. Horner, C. Hardcastle, A. Price, \& J. Bebbington (Eds), International Conference on Whole Life Urban Sustainability and its Assessment. Glasgow. 
Mehrizi, M. H. R., Ghasemzadeh, F., \& Molas-Gallart, J. (2009). Stakeholder Mapping as an Assessment Framework for Policy Implementation. SAGE Publications (Los Angeles, London, New Delhi, Singapore and Washington DC), 15(4), 427- 444. https://doi.org/10.1177/1356389009341731

Moleong, L. J. (2002). Metode Penelitian Kulitatif [Qualitative Research Methods]. PT Remaja Rosdakarya.

Neergaard, H., \& Ulhøi, J. P. (2007). Handbook of Qualitative Research Methods In Entrepreneurship. Edward Elgar Publishing, Inc.

Pandey, V., \& Gupta, S. (2016). Understanding G2G e-government project impasse. Information Development, 33(4), 361-374 . https://doi.org/10.1177/0266666916657582

Reed, M. S., Graves, A., Dandy, N., Posthumus, H., Hubacek, K., Morris, J., Prelle, C., Quinn, C. H., \& Stringer, L. C. (2009). Who's in and why? A typology of stakeholder analysis methods for natural resource management. Journal of environmental management, 90(5), 1933-1949. https://doi.org/10.1016/j.jenvman.2009.01.001

Shirey, M. R. (2012). Stakeholder Analysis and Mapping as Targeted Communication Strategy. JONA: The Journal of Nursing Administration, 42(9), 399-403. https://doi.org/10.1097/nna.0b013e3182668149

Tomkiv, Y., Liland, A., Oughton, D. H., \& Wynne, B. (2017). Assessing Quality of Stakeholder Engagement: From Bureaucracy to Democracy. Bulletin of Science, Technology \& Society 2017, 37(3), 167-178. 2019. https://doi.org/10.1177/0270467618824027

Usadolo, S. E., \& Caldwel, M. (2016). A Stakeholder Approach to Community Participation in a Rural Development Project. SAGE Open, 6(1) 1-9. https://doi.org/10.1177/2158244016638132 